\title{
The 4-aminopiperidine series has limited anti-tubercular and anti-staphylococcus aureus activity
}

\author{
N Susantha Chandrasekera ${ }^{1}$, Torey Alling ${ }^{1}$, Mai Bailey ${ }^{1,2}$, Aaron Korkegian ${ }^{1}$, James Ahn ${ }^{1}$, Yulia Ovechkina ${ }^{1}$, \\ Joshua Odingo ${ }^{1 *}$ and Tanya Parish ${ }^{1}$
}

\begin{abstract}
Background: Tuberculosis (TB) caused by Mycobacterium tuberculosis is the leading cause of death from a bacterial infection. The 4-aminopiperidine (PIP) series has been reported as having anti-bacterial activity against M. tuberculosis. We explored this series for its potential to inhibit aerobic growth of $M$. tuberculosis. We examined substitution at the $\mathrm{N}-1$ position and C-4 position of the piperidine and modifications of the piperidine moiety systematically to delineate structure-activity relationships influencing potency. Compounds were tested for growth-inhibitory activity against virulent M. tuberculosis. A selected set of compounds were also tested for its activity against Staphylococcus aureus.

Results: The compound with a norbornenylmethyl substituent at the N-1 position and N-benzyl-N-phenethylamine at the C-4 position of the piperidine (1) was the only active compound with a minimum inhibitory concentration (MIC) of $10 \mu \mathrm{M}$ against $M$. tuberculosis. Compounds were not active against $S$. aureus.
\end{abstract}

Conclusions: We were unable to derive any other analogs with MIC $<20 \mu \mathrm{M}$ against $M$. tuberculosis. Therefore we conclude that the lack of activity is a liability in this series precluding it from further development.

Keywords: 4-aminopiperidine, Tuberculosis, Antimicrobial, Staphylococcus aureus

\section{Background}

Tuberculosis (TB) caused by Mycobacterium tuberculosis is the leading cause of death from a bacterial infection. In 2010, according to the World Health Organization (WHO), 8.8 million new cases and 1.4 million deaths from the disease were reported [1]. In addition, more than 2 billion people globally are infected. Of these individuals with latent infection, approximately $10 \%$ are expected to develop active TB in their life [2]. Currently the recommended first-line TB treatment regimens require a minimum of 6 months of multidrug therapy, resulting in challenges with patient adherence. The result of inadequate therapy and poor compliance has contributed to a rise in the emergence of multidrug resistant (MDR) and extensively drug-resistant (XDR) strains of M. tuberculosis [2-6]. Hence, there is an urgent need to

\footnotetext{
* Correspondence: Joshua.Odingo@idri.org

${ }^{1}$ TB Discovery Research, Infectious Disease Research Institute, 1616 Eastlake Avenue E, Seattle, WA 98102, USA

Full list of author information is available at the end of the article
}

develop novel anti-TB drugs that are effective against both drug sensitive and resistant $M$. tuberculosis [2].

The 4-aminopiperidine (PIP) series was reported as a new class of compounds with activity against $M$. tuberculosis in a high-throughput cell-based assay [7]. Of the 14 compounds reported, 4 gave $>90 \%$ inhibition of growth in a single point assay at $10 \mu \mathrm{g} / \mathrm{mL}$. All of these actives were N-benzyl-N-phenethyl-1-arylpiperidin-4-amines. As a part of our ongoing TB drug discovery program, we were interested in exploring the potential of the PIP series to be developed as a lead series for tuberculosis treatment. We conducted an exploratory structure-activity relationship study to evaluate the series for their activity against $M$. $t u$ berculosis as well as against staphylococcus aureus. We tested compound cytotoxicity (TC50) against eukaryotic cells using the Vero cell line (derived from African green monkey kidney cells). 


\section{Results and discussion}

We investigated the activity of the series against a virulent strain of $M$. tuberculosis in liquid culture under aerobic growth conditions [8]. First, we probed the consequences of varying the type of substituents at $\mathrm{N}-1$ position of compound $\mathbf{a}$, while the substituent at the $\mathrm{C}-4$ position was kept constant. Only the compound with the norbornenylmethyl substituent at N-1 position (1) showed good activity with a minimum inhibitory concentration (MIC) against $M$. tuberculosis of $10 \mu \mathrm{M}$ (Table 1) and is similar to what has been previously reported $(4 \mu \mathrm{M})$ [7]. However its activity against Staphylococcus aureus was $>200 \mu \mathrm{M}$.
The N-1 substituents comprising of aromatic, heteroaromatic and aliphatic groups were all linked to the piperidine via a methylene spacer. The aromatic substituents we tested include benzyl groups with an electron withdrawing $\mathrm{Br}$ group (8) and electron donating OMe group. The aliphatics had an acyclic ethyl group (7) and a cyclic cyclopentyl group (10). The heteroaromatics consisted of two isomeric pyridyl compounds $(\mathbf{4}, \mathbf{5})$ and an indole (3). All these piperidine compounds had the same substituent at the $\mathrm{C}-4$ position, which is $\mathrm{N}$-(2-phenethyl)- $\mathrm{N}$-(benzyl).

Alternative substituents at $\mathrm{N}-1$ position as replacement for norbornenylmethyl group gave no improvement on

Table 1 Activity of $\mathrm{N}$-substituted analogs of the PIP series against $\mathrm{M}$. tuberculosis

\begin{tabular}{|c|c|c|c|c|c|}
\hline Compound & R-group & Mtb. MIC $^{\mathrm{a}}(\mu \mathrm{M})$ & $\% l^{\mathbf{b}}$ & $\mathrm{TC}_{50}{ }^{\mathrm{c}}(\mu \mathrm{M})$ & Staphylococcus aureus $I C_{90}(\mu M)$ \\
\hline 1 & & 10 & - & 28 & $>200$ \\
\hline 2 & $\mathrm{H}$ & $>20$ & $<30$ & 14 & $>200$ \\
\hline 3 & & 20 & - & 1.8 & ND \\
\hline 4 & & $>20$ & $<30$ & 31 & ND \\
\hline 5 & & $>20$ & $<30$ & 21 & ND \\
\hline 6 & & $>20$ & 74 & 12.5 & ND \\
\hline 7 & & $>20$ & $<30$ & 71 & $>200$ \\
\hline 8 & & $>20$ & $<30$ & 66 & ND \\
\hline 9 & & $>20$ & $<30$ & 13 & ND \\
\hline 10 & & $>20$ & $<30$ & 80 & ND \\
\hline 11 & & $>20$ & $<30$ & $>100$ & ND \\
\hline
\end{tabular}

${ }^{\mathrm{a}} \mathrm{Mtb} . \mathrm{MIC}$ is the minimum concentration required to inhibit growth of $M$. tuberculosis completely in liquid culture. MIC is the average of two independent experiments; ${ }^{b} \%$ inhibition of growth at $20 \mu \mathrm{M}$ for compounds with MIC $>20 \mu \mathrm{M}$.

ND: not determined; ${ }^{\mathrm{C}} \mathrm{TC} \mathrm{C}_{50}$ is the concentration required to inhibit growth of Vero cell line by $50 \%$. $\mathrm{TC}_{50}$ is the average of two independent experiments. 
compound activity. In fact all these compounds (Table 1) had MICs above $20 \mu \mathrm{M}$, except an indole derivative (3), with an MIC of $20 \mu \mathrm{M}$. The benzyl derivative (6) also showed some activity achieving $>70 \%$ inhibition of Mtb. growth at $20 \mu \mathrm{M}$ with all other compounds demonstrating no activity $(<30 \%$ inhibition of growth at $20 \mu \mathrm{M})$. Compounds 3 and 9 had previously been reported as having anti-tubercular activity with MIC of $9.4 \mu \mathrm{M}$ and $7.4 \mu \mathrm{M}$ respectively [7]. However, in our assay the MICs were $20 \mu \mathrm{M}$ and $>20 \mu \mathrm{M}$ respectively (Table 1 ). None of the compounds showed any activity against $S$. aureus.

We then investigated the effect of having a broad range of substitutions at the $\mathrm{C}-4$ position of the piperidine ring and piperidine replacements. The biological activity was determined, but none of the compounds were active, with no inhibition, even at $20 \mu \mathrm{M}$ (Table 2). The replacement of the phenethyl group in compound $\mathbf{1}$ by ethyl (22) resulted in complete loss of activity, indicating a requirement for flexible hydrophobic group at this position. Similarly, other replacements of the N-phenethyl-N-benzylamine we tried had a negative impact on the biological activity. In addition we investigated effect of change from piperidine to piperazine or morpholine scaffold. However, all these changes were detrimental to anti TB activity of these compounds. Again, none of the compounds showed any activity against staphylococcus aureus.

Table 2 Activity of piperidine analogs with a carbonyl group of the PIP series against M. tuberculosis<smiles>[R]C1CCN(CC2CC3C=CC2C3)CC1</smiles>

b

\begin{tabular}{|c|c|c|c|c|c|}
\hline Compound & R-group & Mtb. MIC ${ }^{\mathrm{a}}(\mu \mathrm{M})$ & $\% I^{b}$ & $\mathrm{TC}_{50}{ }^{\mathrm{c}}(\mu \mathrm{M})$ & Staphylococcus aureus $\mathrm{IC}_{90}(\mu \mathrm{M})$ \\
\hline 12 & & $>20$ & $<30$ & $>100$ & $>200$ \\
\hline 13 & & $>20$ & $<30$ & $>100$ & $>200$ \\
\hline 14 & & $>20$ & $<30$ & 41 & ND \\
\hline 15 & 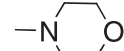 & $>20$ & $<30$ & $>100$ & $>200$ \\
\hline 16 & & $>20$ & $<30$ & 22 & $>200$ \\
\hline 17 & & $>20$ & $<30$ & ND & ND \\
\hline 18 & & $>20$ & $<30$ & $>100$ & $>200$ \\
\hline 19 & & $>20$ & $<30$ & 68 & $>200$ \\
\hline 20 & & $>20$ & $<30$ & $>100$ & $>200$ \\
\hline 21 & & $>20$ & $<30$ & $>100$ & $>200$ \\
\hline 22 & & $>20$ & $<30$ & $>100$ & $>200$ \\
\hline
\end{tabular}

${ }^{\mathrm{a}} \mathrm{Mtb}$. MIC is the minimum concentration required to inhibit growth of $M$. tuberculosis completely in liquid culture. MIC is the average of two independent experiments; ${ }^{b_{\%}} \%$ inhibition of growth at $20 \mu \mathrm{M}$ for compounds with MIC $>20 \mu \mathrm{M}$.

ND: not determined; ${ }^{\mathrm{C}} \mathrm{TC}_{50}$ is the concentration required to inhibit growth of Vero cell line by $50 \%$. $\mathrm{TC}_{50}$ is the average of two independent experiments. 
Then, we explored the influence of replacing the bridging methylene spacer with an amide as in compound 23. Similar amides with different substitutions at the N-1 position and N-4 position are shown on Table 3. Despite the significant changes made at the methylene group and $\mathrm{N}-1$ and $\mathrm{N}-4$ substitutions, there was no improvement in antitubercular activity noted (MIC > $20 \mu \mathrm{M})$.

\section{Conclusions}

We conducted a systematic exploration of the 4aminopiperidine compound series for its inhibitory activity against $M$. tuberculosis. The compound with a norbornenylmethylene substituent at the $\mathrm{N}-1$ position and $\mathrm{N}$-phenethyl-N-benzyl at the $\mathrm{C}-4$ position of the piperidine (1) is a singleton, with a minimum inhibitory concentration (MIC) of $10 \mu \mathrm{M}$ against M. tuberculosis. All the compounds were inactive against $S$. aureus. We were unable to improve the activity in this series, even after significant modifications around the piperidine moiety.
On this basis we concluded that the series lacks further potential for drug development.

\section{Methods}

Determination of minimum inhibitory concentration against $M$. tuberculosis (MIC)

MICs were run as described in [8]; briefly MICs were determined against $M$. tuberculosis $\mathrm{H} 37 \mathrm{Rv}$ grown in Middlebrook 7H9 medium containing 10\% OADC (oleic acid, albumin, dextrose, catalase) supplement (Becton Dickinson) and 0.05\% w/v Tween 80 (7H9-Tw-OADC) under aerobic conditions. Bacterial growth was measured by $\mathrm{OD}$ after 5 days of incubation at $37^{\circ} \mathrm{C}$. The MIC was defined as the minimum concentration required for complete inhibition of growth.

\section{Eukaryotic cytotoxicity assay}

Cytotoxicity was determined against the Vero African green monkey kidney cell line (ATCC CCL-81). Cells

Table 3 Activity of $\mathrm{N}-1$ and 4-substituted piperidine analogs of the PIP series against M. tuberculosis and staphylococcus aureus

\begin{tabular}{|c|c|c|c|c|}
\hline Compound & Structure & Mtb. $M^{\prime} C^{a}(\mu M)$ & $\% \mathbf{I}^{\mathbf{b}}$ & $\mathrm{TC}_{50}{ }^{\mathrm{c}}(\mu \mathrm{M})$ \\
\hline 23 & & $>20$ & $<30$ & 42 \\
\hline 24 & & $>20$ & $<30$ & 47 \\
\hline 28 & & $>20$ & $<30$ & 75 \\
\hline 25 & & $>20$ & $<30$ & $>100$ \\
\hline 26 & & $>20$ & $<30$ & $>100$ \\
\hline 27 & & $>20$ & $<30$ & 37 \\
\hline 29 & & $>20$ & 42 & 13 \\
\hline 30 & & $>20$ & $<30$ & $>100$ \\
\hline
\end{tabular}

${ }^{\mathrm{a}} \mathrm{Mtb}$. MIC is the minimum concentration required to inhibit growth of $M$. tuberculosis completely in liquid culture. MIC is the average of two independent experiments; ${ }^{b_{\%}}$ inhibition of growth at $20 \mu \mathrm{M}$ for compounds with MIC $>20 \mu \mathrm{M}$. ND: not determined; ${ }^{\mathrm{c}} \mathrm{TC}_{50}$ is the concentration required to inhibit growth of Vero cell line by $50 \% . \mathrm{TC}_{50}$ is the average of two independent experiments. 
were cultured in Dulbecco's Modified Eagle Medium (DMEM), High Glucose, GlutaMAX ${ }^{\mathrm{m}}$ (Invitrogen), 10\% FBS (Fetal Bovine Serum), and $1 \mathrm{x}$ of PenicillinStreptomycin Solution (100 units/mL of penicillin, $100 \mu \mathrm{g} / \mathrm{mL}$ of streptomycin). Compounds were solubilized in DMSO (dimethyl sulfoxide) and assayed using a 10-point three-fold serial dilution starting at the highest concentration of $50 \mu \mathrm{M}$. CellTiter-Glo Reagent (Promega) was added to 96-well plates after 2 days of incubation at $37^{\circ} \mathrm{C}, 5 \% \mathrm{CO}_{2}$. Relative luminescent units (RLU) were measured using Perkin Elmer Wallac 1420 Victor2 plate reader. Inhibition curves were fitted using the LevenbergMarquardt algorithm. Toxic concentration (TC50) was defined as the concentration of compound that gave 50\% inhibition of growth.

\section{Determination of activity against Staphylococcus aureus}

S. aureus ATCC 25923 strain was grown in Mueller Hinton II broth at $35^{\circ} \mathrm{C}$ overnight. The overnight culture was diluted in fresh broth and used as inoculum for the antimicrobial screen. Working stocks (50X) of test compounds were prepared in DMSO. Each well of the 384well plate contained $30 \mu \mathrm{l}$ of the inoculum and $0.6 \mu \mathrm{l}$ of the 50X compound working stock. Plates were incubated at $35^{\circ} \mathrm{C}$ for 18 hours and $30 \mu \mathrm{l}$ of the BacTiter-Glo ${ }^{\mathrm{ma}}$ reagent (Promega) was added. Relative luminescent units (RLU) were measured using and normalized to growth control wells (2\% DMSO) and expressed as \% Growth. $\mathrm{IC}_{50}$ values were calculated using the Levenberg-Marquardt nonlinear regression algorithm and defined as the compound concentration that produced $50 \%$ of the growth inhibitory response. The $\mathrm{IC}_{90}$ value was defined as the compound concentration that produced $90 \%$ of the growth inhibitory response $[9,10]$.

\section{Compound purity analysis}

HPLC analysis was conducted on an Agilent 1100 series LC system (Agilent ChemStation Rev.A.10.02; PhenomenexLuna-C18, $4.8 \mathrm{~mm} \times 150 \mathrm{~mm}, 5 \mu \mathrm{m}, 1.0 \mathrm{~mL} / \mathrm{min}$, UV $254 \mathrm{~nm}, 214 \mathrm{~nm}$, room temperature) with $\mathrm{MeCN} / \mathrm{H}_{2} \mathrm{O}$ (0.05\% TFA or $\mathrm{HCOOH}$ buffer) gradient elution. HPLCMS was performed on a Gilson 321 HPLC with detection performed by a Gilson 170 DAD and a Finnigan AQA mass spectrometer operating in electrospray ionization mode using a Phenomenex Gemini C18 $150 \times 4.6 \mathrm{~mm}$ column. All the compounds were purchased from ChemBridge Corporation. Purity was calculated from the LC trace at $214 \mathrm{~nm}$.

1: LC-MS (ESI) $\mathrm{m} / \mathrm{z}: 401.1(\mathrm{M}+\mathrm{H})^{+}, \mathrm{t}_{\mathrm{R}}=0.76 \mathrm{~min}$, purity $>99 \%$.

2: LC-MS (ESI) m/z: $294.9(\mathrm{M}+\mathrm{H})^{+}, \mathrm{t}_{\mathrm{R}}=0.64 \mathrm{~min}$, purity $>99 \%$.

3: LC-MS (ESI) $\mathrm{m} / \mathrm{z}: 423.9(\mathrm{M}+\mathrm{H})^{+}, \mathrm{t}_{\mathrm{R}}=0.79 \mathrm{~min}$, purity $>99 \%$.
4: LC-MS (ESI) $\mathrm{m} / \mathrm{z}: 385.9(\mathrm{M}+\mathrm{H})^{+}, \mathrm{t}_{\mathrm{R}}=0.74 \mathrm{~min}$, purity $>99 \%$.

5: LC-MS (ESI) $\mathrm{m} / \mathrm{z}: 385.9(\mathrm{M}+\mathrm{H})^{+}, \mathrm{t}_{\mathrm{R}}=0.73 \mathrm{~min}$, purity $>99 \%$.

7: LC-MS (ESI) m/z: $323.00(\mathrm{M}+\mathrm{H})^{+}, \mathrm{t}_{\mathrm{R}}=0.70 \mathrm{~min}$, purity $>99 \%$.

8: LC-MS (ESI) $\mathrm{m} / \mathrm{z}: 464.8(\mathrm{M}+\mathrm{H})^{+}, \mathrm{t}_{\mathrm{R}}=3.53 \mathrm{~min}$, purity $>99 \%$.

9: LC-MS (ESI) $\mathrm{m} / \mathrm{z}: 444.9(\mathrm{M}+\mathrm{H})^{+}, \mathrm{t}_{\mathrm{R}}=2.79 \mathrm{~min}$, purity $>99 \%$.

10: LC-MS (ESI) m/z: $363.00(\mathrm{M}+\mathrm{H})^{+}, \mathrm{t}_{\mathrm{R}}=0.71 \mathrm{~min}$, purity $>99 \%$.

11: LC-MS (ESI) $\mathrm{m} / \mathrm{z}: 434.9(\mathrm{M}+\mathrm{H})^{+}, \mathrm{t}_{\mathrm{R}}=4.57 \mathrm{~min}$, purity $>99 \%$.

12: LC-MS (ESI) m/z: $284.00(\mathrm{M}+\mathrm{H})^{+}, \mathrm{t}_{\mathrm{R}}=0.55 \mathrm{~min}$, purity $>99 \%$.

13: LC-MS (ESI) m/z: $271.00(\mathrm{M}+\mathrm{H})^{+}, \mathrm{t}_{\mathrm{R}}=0.73 \mathrm{~min}$, purity $>99 \%$.

15: LC-MS (ESI) $\mathrm{m} / \mathrm{z}: 194.00(\mathrm{M}+\mathrm{H})^{+}, \mathrm{t}_{\mathrm{R}}=0.66 \mathrm{~min}$, purity $>99 \%$.

16: LC-MS (ESI) m/z: $269.00(\mathrm{M}+\mathrm{H})^{+}, \mathrm{t}_{\mathrm{R}}=0.74 \mathrm{~min}$, purity $>99 \%$.

17: LC-MS (ESI) m/z: $275.00(\mathrm{M}+\mathrm{H})^{+}, \mathrm{t}_{\mathrm{R}}=0.54 \mathrm{~min}$, purity $>99 \%$.

18: LC-MS (ESI) $\mathrm{m} / \mathrm{z}: 366.00(\mathrm{M}+\mathrm{H})^{+}, \mathrm{t}_{\mathrm{R}}=0.67 \mathrm{~min}$, purity $>99 \%$.

19: LC-MS (ESI) $\mathrm{m} / \mathrm{z}: 208.00(\mathrm{M}+\mathrm{H})^{+}, \mathrm{t}_{\mathrm{R}}=0.66 \mathrm{~min}$, purity $>99 \%$.

20: LC-MS (ESI) m/z: $235.0(\mathrm{M}+\mathrm{H})^{+}, \mathrm{t}_{\mathrm{R}}=0.69 \mathrm{~min}$, purity $>99 \%$.

21: LC-MS (ESI) $\mathrm{m} / \mathrm{z}: 235.00(\mathrm{M}+\mathrm{H})^{+}, \mathrm{t}_{\mathrm{R}}=0.66 \mathrm{~min}$, purity $>99 \%$.

23: LC-MS (ESI) $\mathrm{m} / \mathrm{z}: 398.9(\mathrm{M}+\mathrm{H})^{+}, \mathrm{t}_{\mathrm{R}}=4.21 \mathrm{~min}$, purity $>99 \%$.

24: LC-MS (ESI) $\mathrm{m} / \mathrm{z}: 404.9(\mathrm{M}+\mathrm{H})^{+}, \mathrm{t}_{\mathrm{R}}=4.12 \mathrm{~min}$, purity $>99 \%$.

25: LC-MS (ESI) $\mathrm{m} / \mathrm{z}: 413.9(\mathrm{M}+\mathrm{H})^{+}, \mathrm{t}_{\mathrm{R}}=4.21 \mathrm{~min}$, purity $>99 \%$.

26: LC-MS (ESI) m/z: $413.9(\mathrm{M}+\mathrm{H})^{+}, \mathrm{t}_{\mathrm{R}}=3.99 \mathrm{~min}$, purity $>99 \%$.

27: LC-MS (ESI) m/z: $456.9(\mathrm{M}+\mathrm{H})^{+}, \mathrm{t}_{\mathrm{R}}=4.53 \mathrm{~min}$, purity $>99 \%$.

28: LC-MS (ESI) $\mathrm{m} / \mathrm{z}: 432.9(\mathrm{M}+\mathrm{H})^{+}, \mathrm{t}_{\mathrm{R}}=4.63 \mathrm{~min}$, purity $>99 \%$.

29: LC-MS (ESI) $\mathrm{m} / \mathrm{z}: 351.00(\mathrm{M}+\mathrm{H})^{+}, \mathrm{t}_{\mathrm{R}}=0.71 \mathrm{~min}$, purity $>99 \%$.

30: LC-MS (ESI) m/z: $323.9(\mathrm{M}+\mathrm{H})^{+}, \mathrm{t}_{\mathrm{R}}=0.71 \mathrm{~min}$, purity $>99 \%$.

\section{Abbreviations}

TB: Tuberculosis; PIP: 4-aminopiperidine; MIC: Minimum inhibitory concentration.

Competing interests

The authors declare that they have no competing interest. 


\section{Authors' contributions}

NC, TA, MB, JA conducted experimental work. NC, AK, YO, JO and TP conceived and designed the experiments, analysed the data and wrote the paper. All authors read and approved the final manuscript.

\section{Acknowledgements}

This research was funded by grant OPP1024038 from the Bill \& Melinda Gates Foundation. We thank Alfredo Blakeley, David Roberts, Stephanie

Florio, and Juliane Ollinger for technical assistance.

\section{Author details}

${ }^{1}$ TB Discovery Research, Infectious Disease Research Institute, 1616 Eastlake Avenue E, Seattle, WA 98102, USA. ${ }^{2}$ Current address: Seattle Genetics, Bothell, USA

Received: 30 October 2014 Accepted: 15 January 2015

Published online: 13 February 2015

\section{References}

1. World Health Organization (WHO). Global tuberculosis control. WHO Report 2011. Document. WHO/HTM/TB/2011.16. Geneva: World Health Organization; 2011.

2. Ginsberg A. Drugs in development for tuberculosis. Drugs. 2010;70(17):2201-14

3. Veluchamy M, Madhavan R, Narayanan S, Rajesh L. KatG gene as a surrogate molecular marker leading to cause drug resistance in Mycobacterium tuberculosis isolates. Am J Infect Dis Microbiol. 2013;1(5):86-91.

4. Parr JB, Mitnick CD, Atwood SS, Chalco KB, Jaime B, Mercedes C. Concordance of resistance profiles in households of patients with multidrug-resistant tuberculosis. Clin Infect Dis. 2014;58(3):392-5.

5. Saifullah B, Hussein MZB, Al Ali SHH. Controlled-release approaches towards the chemotherapy of tuberculosis. Int J Nanomedicine. 2012;7:5451-63.

6. Singla $P$, Singh $R$, Sharma M, Aparna CU. Extensively drug resistant tuberculosis: a mini review. Int J Curr Microbiol Appl Sci. 2014;3(1):219-34.

7. Ananthan S, Faaleolea ER, Goldman RC, Hobrath JV, Kwong CD, Laughon BE, et al. High throughput screening for inhibitors of Mycobacterium tuberculosis H37Rv. Tuberculosis. 2009;89:334-53.

8. Ollinger J, Bailey MA, Moraski GC, Casey A, Florio S, Alling T, et al. A dual read-out assay to evaluate the potency of compounds active against Mycobacterium tuberculosis. PLoS One. 2013;8(4):1-9.

9. Clinical and Laboratory Standards Insitute. Performance Standards for Antimicrobial Susceptebility Testing: Nineteenth Informational Supplement. 2012; M100-S22. Wayne, PA: CLSI; 2009.

10. Fan F, Butler B, Riss T, Wood K. Quantitate microbial cells using a rapid and sensitive ATP-based luminescent assay. Promega Notes. 2004;88:2-4.

\section{Submit your next manuscript to BioMed Central and take full advantage of:}

- Convenient online submission

- Thorough peer review

- No space constraints or color figure charges

- Immediate publication on acceptance

- Inclusion in PubMed, CAS, Scopus and Google Scholar

- Research which is freely available for redistribution 